\title{
Editorial
}

\section{The case for human dignity}

Latino Studies (2011) 9, 373-376. doi:10.1057/lst.2011.53

The lack of visible mass political activity on the part of modern industrial populations is a function of how these societies have been shaped by the various economic or political elites who fashioned them, writes Lawrence Goodwyn in his brilliant analysis of the Populist movement at the end of 19th century in the USA. In fundamental ways, this shaping process bears directly not only on our ability to grasp [concrete social movements], but also on our ability to understand protest generally and, most important of all, on our ability to comprehend the prerequisites for democracy itself (1978: $x-x i)$.

In a speech circa 1890, Mary Elizabeth Lease, political activist and leader of the Populist agrarian revolt of her era, the longest most massive and most maligned democratic movement in the history of the USA, unambiguously declared "Wall Street owns the country. It is no longer a government of the people, by the people, and for the people, but a government of Wall Street, by Wall Street and for Wall Street. The great common people of this country are slaves, and monopoly is the master" (Lease, c. 1890).

Today, over 120 years later, another social movement threatened by the powers that be with political invisibility, the Occupy Wall Street (OWS) movement, is nonetheless spreading rapidly across the country. OWS began on 17 September, when a small group set up tents in Zuccotti Park in downtown Manhattan just a few blocks away from the infamous eye of the financial storm that, since 2008, has wreaked havoc in millions of people's lives around the nation and the world. Like those who joined the Populist movement of the 1890s, adherents of the OWS movements around the country are determined to confront the unchecked power of the banking and credit system, expressing an alternative to the resignation, the feelings of powerlessness, the atomization of our society. Ultimately, they are calling on all working people to come together to (re)take control of their lives and thus expand the meaning and practice of democracy. Challenging the oppressive economic conditions that govern the lives of 99 per cent of the US population today, it is an effort to 
1 Document accepted by The NYC General Assembly. 29 September 2011; Posted on 30 September 2011; http://nycga.cc/ 2011/09/30/ declaration-of-theoccupation-ofnew-york-city/.

2 For an excellent analysis of the media's response cf. Seltzer (2011). reconstitute community, one that emphasizes egalitarianism, justice and cooperation rather than individual advancement, competition and greed:

As one people, united, we acknowledge the reality: that the future of the human race requires the cooperation of its members; that our system must protect our rights, and upon corruption of that system, it is up to the individuals to protect their own rights, and those of their neighbors; that a democratic government derives its just power from the people, but corporations do not seek consent to extract wealth from the people and the Earth; and that no true democracy is attainable when the process is determined by economic power. We come to you at a time when corporations, which place profit over people, self-interest over justice, and oppression over equality, run our governments. We have peaceably assembled here, as is our right, to let these facts be known.

\section{Declaration of the Occupation of New York City ${ }^{1}$}

Despite the increasingly violent response of the police - most recently in New York, Oklahoma and, particularly, Oakland California - and the mainstream media's black out and/or persistent distortions, ${ }^{2}$ the call of the movements of the 99 per cent to take back the power of the people - and to occupy the social and political spaces robbed and mutilated by the rampant deregulated greed of the 1 per cent - has spread to hundreds of cities and towns across the country and around the world. In the process, the growing international movements' activists and participants are affirming that they are "the people" the 99 per cent, with the right to demand that their voices, dreams and aspirations be heard in all spheres and practices of their respective nations.

In the United States, people are coming together peacefully, to give voice and ear to each other's concerns. The fact that broadcasts through microphones and loudspeakers are forbidden at Zuccotti Park by the city of New York, has meant that today, "We the people" are literally using the pure unadulterated human voice as the powerful weapon it has always been to shatter the deafening silence of the mainstream media and politics. Thus, in this dawn of renewal of democracy in the twenty-first century, it is once again the human voice that reverberates from mouth to mouth and from heart to neighbor's heart, providing a glimpse of the irreducible and harmonious plurality that true community brings to life, affirming the visibility of each person, regardless of race, gender, generation, nationality, class, sexual orientation, legal status ... No wonder this presage of the truly possible better alternatives enjoys the support of such distinct personalities as Nobel Prize winner, economist Joseph Stiglitz, journalists Naomi Klein and Amy Goodman, filmmaker Michael Moore, philosopher and critical theorist Slavoj Zizek, Egyptian activist Asmaa Mahfouz and, of course, the grandest of all living public intellectuals, Noam Chomsky. 
In the case of New York, the people have taken over Zuccotti Park, changing its name back to its original Liberty Park. At the Park everyone has a voice - all opinions are heard; decisions are made gradually, slowly, by consensus; the key is respect for one another - the recognition that all are simultaneously leaders and participants - rather than mindless followers and pawns in a political process, a parody of democracy resembling more what some have called "arithmetic pantheism." In this context, the movement's participants urge all people around the world, through their Declaration, to exercise their right "to peaceably assemble; occupy public space; create a process to address the problems we face, and generate solutions accessible to everyone."

Visibility of all - the face-to-face acknowledgement of people's varied experiences and issues and the recognition of the consequent points of view they express - is a key pre-condition for the democratic process to occur in any community, regardless of size - a struggle that has long had to be waged by Latino/as in the United States. Mariné Pérez, a 29-year-old translator and activist from Puerto Rico, has been there "from day one, since 17 September" and, with others, is calling on more Latino/as to join the movement. Together with other translators, she contributed to create a Spanish language newspaper the Occupy Wall Street Journal en español - that has already brought a number of people together, organizing a general assembly in Spanish, and affirming that Latino/as too are part of the 99 per cent (Hinojosa, 2011). "People all over the world are waking up and speaking out ... And there is no going back," Pérez explained, thus emphasizing the US movement's connection with the various mobilizations around the globe (Ruiz, 2011). The call of the OWS Latino/a activists has been heard - and was answered on 7 November by the End to End for 99 per cent march, organized in upper Manhattan's Washington Heights by community leaders and politicians who led hundreds of Latino/as and African Americans, both young and old, on an 11 mile march down to Wall Street at the southern tip of the island. As 81-year-old Altagracia Guzman Vargas, one of the marchers noted, "This [country] belongs to all of us," (Albrecht et al, 2011).

Despite the mainstream media's insistence to the contrary (Cuéntame, 2011), Latino/as and other minorities across the country have indeed joined the movement, calling attention to such issues as the impact of foreclosures and unemployment, currently at higher levels among Latino/as than any other group (Tavernise, 2011), the overwhelming debts that are shackling all students for years to come, the exclusion of thousands of undocumented youth from higher education, the African American and Latino/a-targeted stop and frisk actions of the police, the unrelenting persecution of Latino/a immigrants, the private prisons that are increasingly housing them in growing numbers, and the deportations and family separations that continue to devastate Latino/a families and communities across the country. In so doing, the 99 por ciento are part of the growing movement of American citizens and residents whose actions are 
today recovering the historical democratic movements before them - from the Agrarian Populist revolt of the 1890s, the CIO worker mobilizations of the 1930s, to the Civil Rights activism of the 1950s and 1960s. Emphasizing human dignity and justice they seek to beat back the corporate culture of fear and mistrust that has to date paralyzed the country, and thus re-affirm the value of people over profit, of justice over corporate privilege, of equality, overexploitation and oppression in the twenty-first century.

Pa'lante!

Saludos!

\section{References}

Albrecht, L., B. Fractenberg and C. Zanoni. 2011. Washington Heights March Adds Diversity to Occupy Wall Street. DNAInfo.com, http://www.dnainfo.com/20111107/ manhattan/end-end-marches-solidarity-with-occupy-wall-street, accessed 7 November 2011.

Cuéntame. 2011. The "Whitening" of Occupy Wall Street, http://mycuentame.org/2011/ 11/03/the-whitening-of-occupy-wall-street/, accessed 3 November 2011.

Goodwyn, L. 1978. The Populist Moment: A Short History of the Agrarian Revolt in America. New York: Oxford University Press.

Hinojosa, M. 2011. Latinos in the Occupy Movements Nationwide via @LatinoUSA, http://www.youtube.com/watch?v=_pPTPVRyOdY\&noredirect=1, accessed 22 October 2011.

Lease, M.E.c. 1890. Wall Street Owns The Country. History is a Weapon, http:// www.historyisaweapon.com/defcon1/marylease.html, accessed 4 November 2011.

Ruiz, A. 2011. Latino Occupy Wall Street Protesters Keep Spanish News Flowing in Zuccotti Park. New York Daily News, National Institute for Latino Policy newsletter, 15 October.

Seltzer, S. 2011. Blatantly Biased Tabloids and Clueless Mainstream Media Keep Missing the Obvious Big Story at OWS. Alternet, http://www.alternet.org/story/153001/ blatantly_biased_tabloids_and_clueless_mainstream_media_keep_missing_the_obvious_ big_story_at_ows?page $=1$, accessed 9 November 2011.

Tavernise, S. 2011. Recession study finds Hispanics hit the hardest. The New York Times: 26 July, accessed 1 November.

Suzanne Oboler

John Jay College of Criminal Justice, City University of New York, NY. E-mail: soboler@jjay.cuny.edu 